\title{
CONTINUIDADES, RUPTURAS, DESDOBRAMENTOS: conexões entre cinema indígena, pensamento e xamanismo
}

\author{
Ana Carolina Estrela da Costa $^{1}$
}

\section{Aproximações entre pensamento indígena e cinema}

O pensamento indígena e o pensamento de tradição cristã não são dois termos conceituais absolutamente fechados. Dependendo de como olhamos para o que seríamos "nós" e o que seriam "eles", uma vez delimitados os dois termos como um par a ser ficcionalmente contrastado (Strathern, 2013 [1987]: 42), podemos encontrar relações de oposição, de semelhança, de transversalidade, e tantos desdobramentos dessas relações quanto são possíveis os eixos de comparação considerados. Dito isso, talvez a relação de oposição entre um pensamento ameríndio (ou "selvagem") e um pensamento científicocristão ("ocidental") que mais tenha rendido desdobramentos na literatura etnológica tenha sido aquela apontada por Lévi-Strauss em "O Pensamento Selvagem" (2007 [1962]), e trabalhada em toda a obra deste autor. Para Lévi-Strauss, o pensamento ameríndio ou mitológico, "Ciência do Concreto", "esse bricoleur, elabora estruturas organizando fatos ou resíduos dos fatos, ao passo que a ciência [...] cria seus meios e seus resultados sob a forma de fatos, graças a estruturas que fabrica sem cessar e que são suas hipóteses e suas teorias" (2007 [1962]: 36).

A obra de Lévi-Strauss demonstra que esse pensamento se produz em torno da experiência sensível e se reformula de um modo dinâmico, a partir dos pontos de vista que, sabemos, entre os ameríndios está no corpo-, de um modo que as relações entre dois termos necessariamente os transforma. Uma das consequências mais profundas que se tira daí é a inviabilidade de um sujeito que concebe todo o resto do mundo como um objeto a ser desvendado e categorizado. O que o pensamento indígena produz são, antes de tudo, relações.

Experimentando pensar os mitos ameríndios através de um pensamento composto pelo próprio pensamento mitológico e por seu pensamento científico, Lévi-Strauss nos apresenta um motor infindável de relações que, como um filme e seus planos, são sempre

\footnotetext{
${ }^{1}$ Universidade de São Paulo, Brasil
} 
fragmentos. A célebre ponderação "isso não é tudo" serve tanto para os mitos e seus sistemas quanto para o cinema. Nas Mitológicas, o que se põe em jogo são recortes de amplos contextos (históricos, geográficos, sociológicos), conectados a olhares minimalistas para termos (biológicos, sobrenaturais, sociais, com procedimentos matemáticos, narrativos, linguísticos), seguidos de ligações transversais (entre relações: Cru e Cozido, de onde deriva Ensopado e Assado) e mudanças de perspectiva (um termo é uma coisa em relação a outro termo, e cada um passa a ser outra coisa em relação ao próximo, e assim por diante); largas e aceleradas passadas de um território a outro, de uma classificação a outra, contemplações quase estáticas, pequenos deslocamentos e mudanças de direção. O Bolero de Ravel, mas também a realização de um filme. Um roteiro com muitos ritmos, planos longos e cortes rápidos, uma decupagem às vezes preciosista e às vezes despretensiosa, experiências com foco, planos abertos, fechados e médios.

Lévi-Strauss insiste que esse filme Mitológicas é sobre o pensamento, sobre como os mitos pensam o mundo, sobre o discreto, e não sobre o contínuo. Mas sabemos também que a forma se converte no conteúdo de outra forma, e vice-versa. No último capítulo do Homem Nu (2011 [1971]), o autor esclarece que o estruturalismo permite conciliar "sensível e inteligível, qualitativo e geométrico, e deixa entrever a ordem natural como um vasto campo semântico" (2011 [1971]: 665). E, adiante, afirma que o pensamento estrutural só emerge no espírito humano, trazendo à consciência verdades profundas e orgânicas, porque já está no corpo. O autor nos apresenta uma análise musical do Bolero de Ravel, relacionando seus elementos com as sensações provocadas no ouvinte - embora não esclareça que se trata de um certo tipo de ouvinte, habituado ao sistema tonal e identificado com a tradição musical cristã-europeia -, para demonstrar que as operações do intelecto estão relacionadas, respondendo aos questionamentos de alguns de seus críticos, a operações estéticas e a emoções. No entanto, esclarece que pretende explicar as operações intelectuais dos mitos, porque são elas é que possuem a mesma natureza da própria atividade do pensamento que busca compreendê-los. E acrescenta que operações do sensível poderiam ser decifradas por operações intelectuais, mas a partir de uma escala infinitamente reduzida, confiando tal empreitada mais "aos avanços da bioquímica" que a uma filosofia que recusa ver a natureza como campo semântico.

Para Lévi-Strauss, os mitos falam sobre as sociedades, e não sobre o mundo. Mas, ao mesmo tempo, enquanto desenvolve seu pensamento - que, por um lado, é desdobrado 
em métodos da linguística, da matemática e desenhado em forma de operação musical, e, por outro, deixa-se operar como o próprio pensamento indígena para realizar suas conexões e reversões, ampliações e reduções, retomadas de perspectivas, e, sobretudo, para dissolver a categoria cristã-ocidental do sujeito -, não traz apenas uma análise de como pensam as pessoas que compartilham e transformam os mitos. Ele permite que o pensamento mítico - ou talvez um pensamento dual, relacional, com uma face de pensamento científico e outra de pensamento ameríndio, que se reconfiguram de acordo com o olhar que se lança sobre as narrativas e seus contextos - nos apresente um mundo não mais fixamente dividido pela cultura entre Sujeito (os humanos) e Objetos (a natureza), mas no qual natureza e cultura, humanos e animais, parentes e seres celestes distantes, e tantas outras dualidades em perpétuo desequilíbrio, nos apresentem um mundo totalmente diferente do mundo conhecido pela ciência moderna até então: um mundo onde não há um sujeito fixamente localizado no centro de todas as coisas, mas onde as coisas podem ser vistas sob diversos ângulos, com diversas "roupas" e em diferentes dimensões, de acordo justamente com a relação para a qual se olha. De fato, se a raiz de uma batata faz as vezes de Lince, que em outro lugar corresponde à Lua e assim por diante, não é para o indivíduo que esse pensamento olha, mas para as relações possíveis, vistas não de forma estática, mas dinâmica. Essa forma de olhar o mundo certamente transforma o mundo por completo, inverte o mundo, reconfigura-o e redimensiona-o constantemente, dissolvendo seu estatuto de objeto. Ou seja, as Mitológicas estão o tempo todo nos falando sobre outros mundos possíveis, tão possíveis quanto são possíveis os olhares e as lentes que se aplicam sobre ele. Mais uma vez, cinema.

Levando em conta a potência criadora e produtora de continuidades do cinema, cuja origem é etnográfica e está "[n] esse desejo e [n] essa filosofia da alteridade, 'mostrar a cultura do outro para o outro', deixar o olhar e o pensamento do outro penetrarem no pensamento do observador: ou seja, ver o ponto de vista do outro" (Caixeta de Queiroz, 2008b: 103), veremos como tem se dado a produção cinematográfica dos realizadores e coletivos indígenas das Terras Baixas, em ressonância com seus modos de pensamento e de produção de relação.

O cinema indígena é um cinema mais dos corpos do que das palavras, porque sua ontologia deposita nos corpos um lugar central para a constituição de sua socialidade. [...] Sempre acreditei que fazer filme documentário é uma espécie de bricolage, ir a 
cada passo, pé ante pé, tateando o caminho, atento ao que se passa na frente da câmera, colhendo pedaços (que são as imagens) de um "todo" (uma materialidade, uma corporalidade) e de um "tudo" (um imaginário) que se passa fora da câmera, tudo isso sem roteiro prévio (eu diria - ao contrário da ciência e até mesmo de um certo tipo de cinema documentário ou ficcional - sem uma hipótese ou uma idéia prévia). [...] E, nesse sentido, o cinema oferece ao indígena um meio mais eficaz para realizar a sua antropologia nativa ou reversa, da qual já falamos acima, do que a palavra escrita. Dessa maneira o cinema se aproxima da mitologia, do imaginário, do sonho, do mágico, do corpo, da materialidade, ou seja, aproxima-se do pensamento indígena, selvagem e não domesticado. (Caixeta de Queiroz, 2008b: 118)

Caixeta de Queiroz menciona a admiração de Lévi-Strauss ao assistir O Amendoim da Cotia (2005), realizado em grande parte pelos Panará: "Tudo ali é bemsucedido: a escolha dos temas, os lugares, os enquadramentos e a qualidade das imagens é admirável; temos constantemente o sentimento de sermos levados a ver do interior a vida indígena." (2008b: 101). Seria interessante verificar, a partir daqui, motivos pelos quais a produção de um cinema indígena tem seguido caminhos tão distintos das produções acadêmicas indígenas em direção à construção de saberes não colonizados e mais dialógicos.

Mitos, imagens, sons: aberturas e fechamentos, continuidades, fracionamentos e repetições, ressonâncias.

Os mitos constituem sistemas fechados. Mas a análise estrutural também demonstra que esses sistemas se abrem transversalmente para outros, para se fechar em outro ponto, e assim por diante. "A Origem dos Modos à Mesa" (2006 [1968]), por exemplo, começa trazendo relações - oposições, inversões, repetições, simetrias instáveis- entre termos (a rã, uma mulher que pesca e se divide em duas partes, um tronco, a abelha) para, então, trazer relações metafóricas (Lince e criança raptada) e metonímicas (Coiote e Vento, Vento e europeus) entre relações (o "código astronômico", o conjunto "mulher cortada em pedaços" e origem da pesca, e o grupo "viagem de canoa", "passador suscetível" e "dilúvio"), ou articulações entre conjuntos de mitos (o estômago de bisão que, desdobrado, se conecta ou com a rã ou com a mulher, e tudo isso se conectando à lua, cujas manchas são, novamente, mas de outra forma, a rã; as dezenas e as tríades que colocam, lá na frente, astros celestes e adornos em planos paralelos; a canoa atravessada no rio que percorre o céu quando olhada de longe, mas que segue um percurso transversal como, novamente, o tronco ou a mulher-grampo: a rã), e demonstrar assim os sistemas e 
estruturas. Esse aspecto dinâmico da análise estrutural, que nos permite ver um fechamento de um sistema que se conecta a um próximo por um ou mais elementos, nos permite, após uma sequência maior ou menor de sistemas que vão se encadeando um ao outro, perceber que estamos analisando um sistema que contém os outros e que se fecha novamente sobre um outro eixo, e assim por diante.

Não se conecta qualquer coisa a qualquer coisa. O procedimento é averiguar se existe, na área geográfica observada (um pequeno recorte na Colúmbia Britânica ou as Américas do Sul e do Norte, mas nunca o mundo inteiro), um mito que contenha um motivo que possa ser percebido como uma inversão ou uma variação do motivo que abria o mito anterior. A relação entre os dois passa então a produzir sentido e permite delimitar o campo semântico - que deve ser testado a partir de outros elementos de cada um dos mitos - que fecha o novo conjunto. Nesse exercício, cada pequeno detalhe aparentemente insignificante e sem rendimento (uma célula urso, uma pequena túnica, o nome de uma planta) pode, lá na frente, ser redimensionado e estabelecer conexões que tornam a fechar o conjunto em um eixo menor, e/ou abri-lo para um novo conjunto (História de Lince, 1993 [1991]: 128). Esse movimento não para nunca. É interessante notar que, na atividade cinematográfica, tal procedimento conectivo também é valioso. Assim como no Bolero de Ravel e nas Mitológicas, conjugam-se composições infinitesimais num enquadramento, com a composição dos planos e os cortes entre os planos, o encadeamento das cenas. São vários eixos que se superpõem e se entrecruzam, compondo o conjunto final, e uma das habilidades para realizar a grande composição consiste em utilizar - ou encontrar, e isso leva à questão de qual tipo de cinema estamos falando elementos ou motivos que podem parecer insignificantes, mas que crescem num momento seguinte, articulando as cenas.

Mas "O Cinema" pode ser muita coisa. Se pensarmos no cinema puramente ficcional, ainda que alguns grandes mestres o produzam deixando que as transformações e os movimentos do mundo afetem a narrativa, essa proximidade com a mitologia ou com o ritual se perde, em direção ao procedimento literário do romance. Estou considerando, ao contrário, um certo tipo de cinema, mais próximo da noção de documentário, mas um documentário relacional, aberto para o outro, e que tem sido bastante realizado por cineastas indígenas no Brasil (mas talvez não tanto no resto da América, atualmente).

O campo do cinema se aproxima do campo do ritual quando a narrativa se constitui como um processo transformador e criativo, um jogo entre visível e invisível, 
entre observadores e observados, emissores e receptores, sujeitos e objetos. Filmando de modo relacional o outro (o outro parente, o outro animal, o outro ser-mítico ou encantado), é possível reestabelecer um novo contínuo entre os elementos discretos do mito. Recompõe-se uma relação xamânica com o mundo, desestabilizada pelo olhar e os gestos que o outro devolve à câmera ao ser filmado. Num jogo que pressupõe a presença, a partilha do sensível (Rancière, 2004), uma experiência estética e política em que tempos e espaços são atravessados por pontos de vista, o documentário pode ser um exercício de experimentação de perspectivas, que dissolve o sujeito observador nas relações que vão sendo produzidas. ${ }^{2}$

Mas esse cinema, ao mesmo tempo que produz uma continuidade, expõe seu caráter fragmentário por aquilo que escolhe mostrar, por aquilo que coloca no fora-decampo, e por aquilo que escolhe fatidicamente esconder. Para a Jean-Louis Comolli, conforme lemos no prefácio à edição brasileira de "Ver e Poder" (Comolli, 2008), intitulada "Pela continuação do Mundo (com o cinema)", a experiência do documentário é ao mesmo tempo um fazer e um pensar, sendo o lugar do espectador um lugar político, estratégico, em jogo com o lugar da câmera e o lugar do mundo filmado, numa relação em que uns necessariamente afetam e são afetados pelos outros ${ }^{3}$. É possível ver nos filmes - e nas realizações de oficinas e projetos de filmagem com os quais trabalho - esse estatuto transformador da experiência com o cinema, entre observador e observado, em que realidade e construção são inseparáveis. E, além disso, o modo como a montagem, os recortes entre planos, enquadramentos, o dentro-e-fora do campo, correspondem a um todo muito menor do que a experiência na qual se produz - porque um conjunto de fragmentos recortados a 24 ou 29 fotogramas por segundo -, e ao mesmo tempo maior porque uma experiência nova, um mundo recriado, uma sensação de um movimento contínuo, uma continuidade do mundo - do que a soma de cada escolha, ou cada uma das partes.

\footnotetext{
${ }^{2}$ Um dos indícios dessa aproximação com a produção ritual é que a direção costuma ser não de um cineasta autor individual, mas dos mestres dos ofícios e saberes filmados, especialmente dos xamãs, que além de mediarem relações com os "donos" míticos/ancestrais desses saberes, são os grandes mestres justamente do olhar e da escuta: ou seja, justamente do que se põe em jogo na produção cinematográfica.

3 Adiante, Comolli pondera: "Hoje, o problema do documentário não é colocar em cena aqueles que filmamos, mas deixar aparecer a mise-en-scène deles. A mise-en-scène é um fato compartilhado, uma relação. Algo que se faz junto, e não apenas por um, o cineasta, contra os outros, os personagens. Aquele que filma tem como tarefa acolher as mise-en-scènes que aqueles que estão sendo filmados regulam, mais ou menos conscientes disso, e as dramaturgias necessárias àquilo que dizem - que eles são, afinal de contas, capazes de dar e desejosos de fazer sentir" (Comolli, 2008: 60).
} 
Talvez estejamos diante de uma aproximação possível à proposta monadológica, ou fractal, trabalhada por Gabriel Tarde (2007 [1895]). O que Tarde sugere para pensarmos uma teoria social, e, portanto, da relação, e, portanto, da diferença, e que a meu ver se aplica às experiências dos Maxakali (habitantes do nordeste de Minas Gerais, com quem tenho trabalhado) com o vídeo, suspende uma antinomia entre contínuo e descontínuo, entre o que é estático e o que está em movimento; as permanências são postas como devir, relação, diferenciação e continuidade (existir é diferir, e durar é mudar: eis o que a possibilidade de mostrar e esconder, e a escolha pelo ritmo no documentário nos revela). Através das escolhas do cineasta - esse que, entre os ameríndios, nunca é um indivíduo separado dos demais, mas se conjuga como um feixe de relações -, e nas escolhas dos filmados diante da câmera, configura-se um real como dispêndio de possíveis (Tarde, 2007 [1910]: 212), como um caso não abortado do possível e uma virtualidade necessária, potências que tendem a se realizar, mas que necessariamente são abortadas para que os recortes e a criação aconteçam. Ou seja, se a análise estrutural trabalha com a riqueza de elementos discretos, e o ritual religa os humanos à experiência vivida na natureza contínua, o cinema talvez esteja no meio do caminho.

A filmagem funde-se com a experiência ritual, e talvez a montagem seja o que rompe a continuidade do filme em elementos menores - talvez não o suficiente para uma análise estrutural - que serão então reconectados. Trata-se de uma operação que recria uma continuidade a partir das estruturas dos cantos, das fases do dia, da noite e da madrugada, dos espaços internos, externos e afastados. Ao mesmo tempo, como bem disse Lévi-Strauss a respeito da experiência inaugural do cinema entre os Navajo (2006 [1968]: 648), toda a experiência fílmica (no caso apresentado) passa pelo procedimento de fragmentação (introdução da diferença) e da repetição, característico mais da produção dos cantos, mas que não se separa da composição das narrativas míticas. De fato, o que ocorre nesses filmes (amplio o olhar do contexto Maxakali para recentes produções da Terras Baixas, e trago, por este motivo, as primeiras produções dos Navajo, mas não as recentes que tenho visto) é uma característica comum de dar a alguns gestos - o deslocamento, a execução de um canto, uma situação de produção de riso - um maior destaque do que a outros que poderiam parecer, aos olhos de quem não compartilha do que poderia ser o campo semântico do filmado, mais significativos ou representativos. Ou seja, a filmagem produz continuidades e aberturas, desdobrando gestos e olhares em 
novas experiências sensíveis, e a montagem escolhe entre preservar em longos planossequência alguns desses gestos, percursos sonoros ou visuais, e articular imagens e sons mais recortados, que vão, por isso, reunir em si significados mais apreensíveis intelectualmente. Cruzam-se no filme vários eixos em diferentes escalas. A articulação entre dois planos pode produzir uma percepção de continuidade entre um e outro, mesmo se tiver havido um intervalo ou distância entre eles ("Imagem-Movimento" de Deleuze, 1985). Ao contrário, também pode indicar um intervalo que pode parecer maior do que o que ocorreu no momento da filmagem, para produzir a sensação de uma ruptura, de uma grande passagem do tempo entre um movimento e outro ("Imagem-Tempo de Deleuze", 2007).

Mas o procedimento que mais interessa aos cineastas indígenas das Terras Baixas parece ser o longo plano-sequência que partilha a intensidade do próprio procedimento filmado: a caminhada, o ritual, ou qualquer outro gesto que possa então ser revivido mas de outro modo - pelo cinema. Mas não sei se me satisfaço com a hipótese de LéviStrauss de que a "marcha lenta" dos longos e infinitamente detalhados planos indígenas ocorrem porque, ao contrário de um não-indígena, um Navajo teria os olhos mais treinados pelo ritual para perceber as micro-diferenciações do movimento filmado (2011 [1971]: 650). Meu trabalho com cineastas indígenas me leva a acreditar que, mais do que uma percepção mais apurada ou detalhista para os fragmentos que compõem uma sequência filmada, os cineastas e espectadores indígenas preferem deixar que a filmagem reconstitua uma nova continuidade e uma nova experiência vivida, uma repetição variada do gesto ou movimento filmado, que vai se desdobrar em novos gestos a serem revividos e refilmados. Vejo-os rindo por horas, dias, meses, anos a fio diante de uma imagem que produz o riso, assim como vejo-os chorando sempre que alguém que já morreu reaparece em cena.

Existe uma tendência de produzir-se um cinema de natureza fracional e constitutiva de um sistema discreto e articulado, não tanto análoga ao mito mas à produção literária do romance, e que passa por um processo didático, de compreensão da linguagem tradicional do cinema a partir de referências específicas. Isso é ensinado a cineastas aprendizes indígenas e não indígenas. Recursos como a inserção de trilhas sonoras que intensificam possibilidades representativas levam, em parte, a um tipo de produção cinematográfica mais homogênea, mas também permitem desdobramentos entre novos sentidos que podem ser conectados. Mas os filmes que considero aqui estão 
muito mais dedicados a uma ressonância entre a produção e o compartilhamento do discurso material gravado na película (ou na memória da câmera), e procedimentos de natureza xamânica, de reestabelecimento de continuidades a partir da percepção e da produção de diferenças infinitesimais, da relação com um outro cosmopolítico, que incorpora os seres humanos, não humanos, encantados, as "coisas" que também são gentes.

A ação de filmar, nesse tipo de cinema que estou considerando, não é um gesto de captura de um objeto de natureza passiva, ou de uma realidade pronta. Filmar é construir um encontro, e a câmera tem uma função muito mais de agenciadora de relações possíveis do que de um artefato inerte, não-humano, impossibilitado de aceder a um ponto de vista ${ }^{4}$. A câmera pode proporcionar, conforme tem me dito meus interlocutores, à maneira de um xamã, uma continuidade entre o visto e o que vê, entre o visto e o não-visto. Muitas vezes o gesto de filmar se mistura ao gesto filmado, e por esta razão tantas experiências, análogas ao "cine-transe" de Jean Rouch (Rouch, 2003 [1973]: 63), tem sido chamadas de "cine-ritual" (Caixeta de Queiroz, 2008, Brasil, 2012, Estrela da Costa, 2015a). Claudine de France (1998 [1982]) chama a atenção para as relações entre a temporalidade e a espacialidade desenvolvidas pelo filme - nas escolhas de enquadramentos, ângulos e movimentos da filmagem, assim como na construção rítmica, temporal e espacial da montagem - e pelo ritual -, na mise-en-scène ritual, incluindo-se aí a presença da câmera nas relações estabelecidas. A etnografia fílmica, segundo a autora, traria a impossibilidade de separar, num plano dos fatos sensíveis, aquilo que a escrita nos ensinou a dissociar mentalmente. É aí que o filme se afasta da ciência e da análise estrutural.

As técnicas fílmicas articulam-se com as técnicas filmadas e as relações filmadas convergem com as relações estabelecidas entre as pessoas filmadas, a câmera e o filmador - e, em outro eixo, os espectadores. Desse modo, será que esse sujeito (já chamado de câmera) não se dissolve um pouco nas relações que experimenta e produz? Mas campo visual que o filme instaura não se confunde nem com o ponto de vista dos espectadores

\footnotetext{
${ }^{4}$ A perda da estabilidade de um modo de apreensão objetiva pela câmera permite que entremos, com nosso olhar e nosso próprio corpo, em ressonância com aquilo que é, por si só, uma produção ritualística de subjetividades e de ressonância entre corpos e olhares. Quem filma não é mais apenas um observador, mas um participante compósito e desdobrável, na medida em que o filme afeta e é afetado pelo ritual. As imagens e seus corpos se constroem a partir da interação entre os que olham e são olhados, reciprocamente. A câmera produz a imagem que é produzida pelos filmados, e seu ponto de vista, tanto quanto qualquer outro, transforma e ao mesmo tempo se sujeita às relações produzidas no ritual.
} 
da aldeia, nem com o dos corpos filmados. A câmera é um outro corpo posto em relação no ritual, que precisa se aproximar para dar a ver, em primeiro plano, pinturas e adornos, e se afastar para que seja possível perceber um movimento maior, num contínuo exercício da "boa distância". Entretanto, e só a etnografia dos momentos de produção permite concluir, o olhar da câmera é composto por muitos olhares numa aldeia indígena. Além disso, "ser olhado" não necessariamente denota uma ação passiva, mas pode ser um gesto xamanisticamente afetante (Kopenawa \& Albert, 2010: 66-114).

Caixeta de Queiroz (2008b) ensaia algumas relações entre o estruturalismo de Lévi-Strauss (e a passagem ritual do descontínuo ao contínuo) a procedimentos do cinema conforme pensado por Bergson, para quem "O cinema é um sistema que reproduz o movimento a partir de um momento qualquer, isto é, em função de instantes equidistantes escolhidos de maneira a dar impressão de continuidade". Bergson, que, para LéviStrauss, pensava como um Sioux,

\begin{abstract}
não queria compreender as "poses eternas" (os cortes imóveis) tal como supõe o primeiro pensamento fotográfico ou a filosofia da "eternidade", mas gostaria de compreender o próprio movimento da vida e do pensamento, e, por isso, antecipou os "cortes imóveis" da duração próprios ao cinema. Enfim, podemos dizer que Bergson procurou desvendar os mecanismos pelos quais desvendamos os fluxos dos seres e das coisas, e, sem que saibamos, ao fazer isso, acionamos um dispositivo irracional (ilusório, sensível), que é o próprio dispositivo cinematográfico. (2008b: 200)
\end{abstract}

Como pontua Caixeta de Queiroz, o cinema de Bergson, tal como o procedimento das Mitológicas e o próprio pensamento mitológico, utiliza "paragens" no mundo dos seres e das coisas para buscar compreender o movimento. Afinal, cada fragmento do movimento, em perpétuo desequilíbrio, contém uma abertura para outros movimentos operados pela apreensão sensível. De fato, ao mesmo tempo em que o cinema pode possuir um aspecto eternizador, sua grande potência está em criar continuidades e esquecimentos. No sentido inverso da experiência pré-cinematográfica realizada por Muybridge e Marey com a cronofotografia - decomposição do movimento de animais e pessoas por fotografias disparadas a cada fragmento desse movimento, com o objetivo científico de apreender essas etapas imperceptíveis a olho nu -, está uma produção que, quase sempre, circula entre as casas das aldeias e se repete à exaustão, mas que depois se apaga ou se perde como se já não fizesse sentido. Afinal, cada filme produzido enseja a produção de suas variantes subsequentes: um novo filme ritual, um novo filme de caçada, e assim por diante. 


\section{"Isso É Cinema": Olhar Como Forma de Resistência}

A mostra "O Olhar Como Forma de Resistência", no Festival de Cinema e Documentário Forumdoc.2016, na UFMG, reuniu dezenas de realizadores indígenas, especialmente da América Latina, exibindo e comentando seus trabalhos. No cerne dos debates, a demanda pela ocupação, descolonização e transformação de instituições através do vídeo. Foram vistas, lado a lado, experiências contrastantes, como, por exemplo, vídeos e falas de cineastas da Bolívia, que conquistaram um espaço significativo no âmbito das políticas públicas nacionais, com redes de rádio e TV e centenas de produções.

Mas ficou evidente, durante a mostra, que coletivos e cineastas das terras baixas, como os Maxakali, Krahô, Xavante, Huni Kuin, Guarani, Kuikuro, Cinta Larga, Kaiowá, Kalapalo, cada um a seu modo, têm produzido um cinema muito distante daquele formato de documentário em que uma voz em off explica um contexto, as pessoas respondem a entrevistas, e as imagens ilustram o assunto ao som de uma trilha sonora. Enquanto a estratégia de cineastas e coletivos da América Latina, de modo geral, pareceu ser produzir um material a partir das demandas locais para contrapor suas lutas à invisibilização nos meios de comunicação de massa, o cinema indígena brasileiro ali mostrado, em sua maioria filmes-rituais - ou rituais-filmes, ou filmes-caça, filmes-pesca (Estrela da Costa, 2015b) -, não se incomoda se o evento filmado não é completamente explicado. Ele se desprende de um roteiro prévio (mas também se desprenderá de estruturas do pensamento? Lévi-Strauss nos diria que não) e se põe em risco, admitindo que filmadores e filmados construam o filme ao mesmo tempo em que produzem aquilo que se filma.

Sendo assim, filmes como "Kêtuwaje - Festa de Iniciação dos Jovens" (2013), realizado por um coletivo Krahô, e "Iniciação dos Filhos dos Espíritos da Terra" (2015) de Isael Maxakali, que não necessariamente trazem um discurso político, entendida a política como disputa pelo poder e negociação de direitos, constituem eles mesmos um exercício político-relacional de negociação através do olhar e da escuta. Eles trazem os espectadores a uma experiência específica que suspende o tempo da "informação" e convoca nosso olhar e nossa escuta para o encontro em que consiste o momento da filmagem. Talvez por isso, terminado o filme Krahô, num dos últimos dias da mostra, o cineasta xavante Divino Tserewahú tenha dito em voz alta: "isso é que é cinema, indígena mesmo, pode registrar no cartório". Tal declaração parece ter vindo do reconhecimento, 
ali, da política relacional de um olhar que não só captura, mas, de maneira controlada, estabelece uma relação, em contraposição ao poder mais informativo ${ }^{5}$ dos filmes de outros ameríndios exibidos na mostra.

Em alguma medida, é importante lembrar que a maioria dos cineastas indígenas do Brasil compartilham uma formação inspirada nas propostas do cineasta etnólogo Jean Rouch, trazida sobretudo através do projeto Vídeo nas Aldeias, e cuja produção inspira outros formadores e constitui uma grande referência de cinema que circula entre as aldeias. Veremos adiante como o cinema de Jean Rouch e a formação proposta por sua escola (Nanterre e Ateliers Varan) constitui-se como uma experiência que, antes de buscar conduzir um olhar à serviço de um cinema que mostre - que "informe"... - uma realidade etnográfica, busca utilizar o cinema como tecnologia a serviço da partilha de experiência, ou da produção inventiva ${ }^{6}$ de uma verdade, admitindo o diálogo interétnico e a incompletude essencial do momento etnográfico e dos pontos-de-vista como possibilidade fundamental de uma antropologia compartilhada e do que Rouch considerava um "cinema-verdade" (Rouch, 1979 [1973]: 32).

Diferentemente da escrita, o cinema se permite, por sua própria natureza sensível e perspectiva, ser capturado mais imediatamente como dispositivo relacional, realizandose numa maior consonância com modos de produção e circulação de saberes não objetificados. Os pontos de vista envolvidos numa relação através da câmera e na

\footnotetext{
${ }^{5}$ Sobre a diferença entre a informação e a narração, podemos pensar com Walter Benjamin (1994 [1936]), para quem a informação, forma de comunicação que ascendeu com a consolidação da burguesia e a criação da imprensa, constitui-se como um saber localizado no espaço e no tempo, fechado em si e passível de verificação e explicação (1994 [1936]: 202). A narração, ao contrário, seria uma forma de partilhar experiências que não se encerram com a transmissão, mas que produzem no ouvinte o desejo e a capacidade de retransmiti-las a partir de novas conexões. O narrador lida artesanalmente com a memória e os saberes, descrevendo as circunstâncias a partir de um ponto de vista, permitindo que seus ouvintes incorporem suas experiências e seus conselhos. A informação segue uma lógica do mercado, é capturável pelos ouvintes. A narração convoca o ouvinte a acompanhar o narrador, e a incorporar, a partir das palavras, dos gestos e das imagens produzidas e das reminiscências provocadas, a experiência que se quer partilhar - sendo uma forma de comunicação que não propõe uma captura, mas uma transformação entre quem narra e quem recebe a narrativa.

${ }^{6}$ Pensemos a invenção num sentido próximo àquele proposto por Roy Wagner (2010[1975]), para quem as "realidades são o que fazemos delas, não o que elas fazem de nós ou que nos fazem fazer" (Ibidem: 23), e o real está mais na relação do que nas coisas que ela relaciona (Ibidem: 30). Inventar é "tornar visível" (Ibidem: 31), é realizar um esforço tradutivo e analógico a partir da experiência e da articulação de universos simbólicos, "de modo que um conjunto de impressões é recriado como um conjunto de significados" (Ibidem: 41). Nesse sentido, Jean Rouch (2003b: 186) fala sobre a ideia de um "transe criativo" experimentado durante a filmagem de um ritual Songay, no qual a câmera se tornou um "objeto ritual", propositor de um ponto de vista e de uma relação na qual o "real" e o "imaginado" se intensificam. Tratase do oposto de uma objetificação: "inventar", nesse sentido, é assumir uma distância e descrever a relação a partir de um ponto de vista. Podemos conceber essa "invenção" como um processo em contínua transformação e desdobramento, que se segue com o gesto também inventivo do espectador (cf. Comolli, 2008 [1988]; Rancière, 2008, 2009).
} 
construção discursiva a partir das imagens e dos sons dão a ver, na sua incompletude essencial, uma realidade mais assumidamente "inventada" e conectada com o momento etnográfico em questão. A realização cinematográfica abre a compreensão e a experimentação do mundo para uma multiplicidade de perspectivas, afastando-se do risco iminente de uma descrição totalizante, autoritária e objetificante de um "povo", uma "cultura", um contexto.

\section{Um campo melhor enquadrado}

As reflexões aqui compartilhadas provém de um extracampo: meu campo etnográfico junto a cineastas Maxakali, que julgo necessário enquadrar por um instante.

Os Maxakali habitam a região do vale do Rio Mucuri, no nordeste de Minas Gerais, e foram alocados pela Funai em territórios pequenos e totalmente devastados pelo avanço das pastagens durante o processo de colonização da região. Tal processo foi extremamente violento, tanto com os Maxakali quanto com a exuberante Mata Atlântica que havia ali. Tendo sido a mata devastada, com a extinção da maioria dos animais e plantas da região; e tendo sido muitos deles dizimados (na década de 60 eram menos de 50 pessoas), considerando que entre eles, cada um dos conhecimentos, dos mitos e dos cantos costumam pertencer a um dono; era de se supor que, hoje, por mais que a população tenha crescido (hoje são cerca de 2000 pessoas), muitos desses conhecimentos e práticas teriam se perdido.

Entretanto, sabemos que hoje eles mantem um corpus mítico-sonoro com pelo menos dez grandes rituais diferentes, e pelo menos dez mil cantos diferentes, muitos dos quais descrevem com riqueza impressionante de detalhes os animais, plantas, lugares e eventos da Mata Atlântica. A aquisição, a produção ou atualização desses saberes se dá a partir de um processo de relações que se estabelecem diariamente, nos rituais, com os yãmĩy, que são os muitos e diferentes seres que em algum momento mítico se encantaram e se tornaram aliados xamânicos dos Maxakali.

Desde a primeira vez que estive em campo, como eu tirava muitas fotos e mostrava, fui sendo de certa forma levada a criar a relação especifica que tenho hoje nas aldeias: de professora de oficinas de vídeo. Isso me coloca num lugar mediado pelos pajés, ou yãyãs (mais velhos no xamanismo) que são os que se comunicam com os yãmĩy - os yãmĩy, também chamados de koxuk (termo traduzido como imagem, sombra, alma) 
quando se dão a ver, são preferencialmente os filmados, nos rituais e nas caçadas -; e pelos caciques, também yãyãs (mais velhos na organização prática das aldeias, orientações, mediação e tomadas de decisão), que são os que asseguram que a vontade da "comunidade" seja seguida. O que eu ensino são técnicas especialmente de edição (ou ao menos o uso do software), em oficinas que constituem eventos ou momentos, entre quinze dias em um mês, em que, privilegiadamente, filmes são produzidos e postos para circular, ao menos entre as aldeias.

Como os yãmĩy são os donos de cada um dos saberes e práticas, e fundamentais para a formação do olhar e da escuta - habilidades fundantes do cinema -, as relações que se produzem nos rituais e caçadas, e, consequentemente, as relações que se produzem por meio do cinema, são coordenadas e orientadas pelos pajés e pelos caciques, cada um a seu modo responsáveis pelo controle das relações entre humanos e das relações perigosas com os "outros" através do olhar e da escuta.

Isso faz com que os filmes Maxakali, de um modo semelhante aos filmes de outras etnias brasileiras, tenham uma temporalidade e um ritmo específicos, e uma relação de mise-en-scène muito cuidadosa com o olhar e a escuta entre quem filma e quem e filmado. O controle exercido pelos pajés e pelos caciques indica que o cinema está sendo apropriado de maneira autônoma ${ }^{7}$ e condizente com seus modos de se organizar e pensar o mundo. Mas, além disso, indicam a impossibilidade de uma essencialização dos Maxakali como um povo homogêneo e dos yãmĩy como categoria cosmológica fixa, uma vez que as relações com os diversos aliados xamânicos só são possíveis na medida em que são atualizadas, e de acordo com quem os está convocando ou relembrando: uma pessoa nunca é dona exatamente dos mesmos cantos que a outra, e é a combinação de cantos e saberes contidos nesses cantos que vai determinar como e com quais yãmĩy se dará aquele encontro xamânico específico, ou aquela narrativa mítica, ou a realização de determinada atividade. A tradição só é viável a partir da variabilidade que a constitui ${ }^{8}$. Por isso os yãyãs não podem abandonar sua responsabilidade de cuidar e controlar a experiência relacional do olhar e da escuta dos demais.

\footnotetext{
${ }^{7} \mathrm{E}$ que, por isso mesmo, não exclui a possibilidade de apreensão do novo e da escolha de algumas referências vindas de fora. Essa autonomia e seus caminhos ainda precisa ser melhor descrita numa oportunidade futura.

${ }^{8}$ Isso ocorre de um modo análogo ao já tão profundamente analisado por Lévi-Strauss, que nos apresenta os mitos ameríndios como sendo compostos por suas variações, inversões e atualizações.
} 
Além disso, fica evidente a inviabilidade de uma autoria simplesmente individual neste contexto. Não se trata de definir os Maxakali simplesmente como sendo um povo sem a noção de indivíduo, mas, antes, compreender que a pessoa Maxakali é um compósito das relações que estabelece ao logo da vida (com outros Maxakali, com nãoindígenas, com yãmĩy). Cada pessoa carrega uma série, ou uma rede de relações, de modo que múltiplos pontos de vista se associam a cada evento. Os pontos de vista implicados nas relações do cinema - nas relações cosmopolíticas que se estabelecem desde as negociações e a organização para a realização dos projetos, até a relação fílmica propriamente dita e os modos de fazer circular o resultado imagético-sonoro final carregam o que talvez seja uma economia simbólica da alteridade. Cabe a nossas descrições e análises - eis uma proposta de pesquisa a respeito do cinema indígena identificar a visibilidade e a materialidade dos corpos que, por meio do xamanismo e também por meio do cinema, se constituem por olhares ${ }^{9}$.

A respeito de narrativas autobiográficas amazônicas, Suzan Oakdale (2007) descreve, por meio de exemplos, como essas narrativas demonstram um sujeito que se move por entre de uma variedade de gentes e incorpora a alteridade em sua formação corporal. Pierre Deleage (2007) descreve como os cantos autobiográficos Caqui Caqui dos Yaminawa subvertem uma noção de pessoa que corresponderia a uma noção de indivíduo e de autoria, trazendo vozes compósitas e conectando o ponto de vista de quem se descreve e descreve seu mundo ao momento performático da enunciação e à indexicalidade dos cantos (2007: 91). Assim como narrativas autobiográficas, o cinema também expressa como se forma e como se concebe o sujeito e suas relações no contexto ameríndio.

Os filmes realizados por indígenas brasileiros exemplificados por aqueles exibidos no Forumdoc.2016 não costumam trazer uma narração em off interpretando e analisando as cenas filmadas. Em alguns casos, há algum personagem - que pode ser inclusive o filmador - que esclarece, não de modo autoritário mas assumindo um ponto de vista - a respeito do contexto das imagens, normalmente a partir de narrativas

\footnotetext{
${ }^{9}$ Talvez seja necessário um grande esforço de tradução para que tal análise apareça. É o que nos permite, por exemplo, A Queda do Céu (2015), onde Davi Kopenawa e Bruce Albert vão, pouco a pouco, demarcando seus lugares de fala e seus pontos de vista. Kopenawa narra um pouco de sua formação xamânica, utilizando os recursos comparativos que seu longo contato com a sociedade de tradição cristã (os "Brancos") lhe permitiram compreender. A apreciação dos filmes etnográficos ameríndios exige, antes de qualquer análise, a experimentação de um ou mais pontos de vista, e nos colocam diante de modos de saber e fazer, mais do que trazem conhecimentos específicos.
} 
míticas ${ }^{10}$. Nos filmes realizados por Rouch e seus companheiros, a idealização do roteiro ou do tema era partilhada, mas também a filmagem e principalmente a captação do áudio. O pacto etnográfico entre cineastas indígenas e antropólogos e cineastas não indígenas se dá fundamentalmente no processo de aprendizagem e produção dos filmes, e não tanto nas camadas interpretativas pós-sincronizadas com as imagens como ocorria nos filmes de Rouch ${ }^{11}$. É preciso levar em conta que, embora o estilo Rouch e dos Ateliers Varan seja em grande parte de filmar editando, ou seja, realizando com a câmera os cortes que construirão a narrativa, a edição final só muito recentemente tem sido feita por alguns cineastas indígenas. A edição feita por não-indígenas ou compartilhada com cineastas e interlocutores e mestres, mas tecnicamente conduzida por não indígenas traz mais um plano de compartilhamento - e que sempre corre o risco de produzir um discurso colonizador e autoritário através das decisões a respeito dos cortes - de vozes e pontos de vista na realização desses filmes.

Um cinema produzido com autonomia por realizadores indígenas pode ser fruto de alianças com os não-indígenas com quem se relacionam. São professores, montadores e co-autores ${ }^{12}$ que assumem acordos com as comunidades onde os projetos são feitos, e acabam entrando na relação fílmica como mais um olhar e uma voz que se acrescentam

\footnotetext{
${ }^{10}$ Laura Graham (1995) descreve um acontecimento performático ocorrido entre os Xavante, e chega à conclusão de que só foi possível compreender o modo pelo qual as pessoas envolvidas eram afetadas e realizar melhor sua tradução e registro, na medida em que tomava conhecimento das narrativas míticas invocadas nos cantos, nos gestos e na apresentação corporal observados. A autora percebe que o discurso - na "fala cerimonial" - se compõe a partir de uma combinação de múltiplas vozes que se intensificam. Ali, ao contrário do modelo dito ocidental de enunciação e relação social e política, o discurso recebe um tratamento que necessariamente dissolve a noção de indivíduo em uma intersubjetividade coletiva. Mas não se trata de um coletivo homogêneo, e sim de uma enunciação compósita e variável. A fala pública é elaborada por meio de técnicas e estratégias - repetições e variações, entonações específicas, falas indiretas e sobrepostas, por exemplo (1995: 200) - para que seja possível compartilhar a experiência narrada. Ora, ainda que os eventos descritos por Graham fossem filmados por um cineasta Xavante, o conteúdo mítico relativo às performances e cantos precisariam de alguma forma ser narrados para que o contexto fosse melhor esclarecido: não basta ser Xavante para conhecer todas as histórias. O modo como as ditas "falas cerimoniais" são construídas polifonicamente poderia ser filmado, mas a relação fílmica por si só não poderia trazer uma análise a respeito da noção de pessoa xavante, por exemplo. Os filmes-rituais produzidos por Divino Tserewahú (2001, 2003, 2009, dentre outros) trazem a experiência ritual e as relações políticas mediadas pela câmera em sua incompletude e intensidade características: afinal, ali, é aos poucos e de modo fragmentário que se toma conhecimento do contexto mítico, e é a partir da experiência que os sujeitos compõem-se politicamente.

${ }^{11}$ Lembrando que as condições técnicas na época em que Jaguar e Moi, un Noir foram feitos não permitiam, por exemplo, a captação do som direto.

${ }^{12}$ Seria esse caso semelhante à participação de alguns orientadores na pesquisa de antropólogos indígenas? Mutua Mehinaku (2010) explicita bastante a influência direta de sua orientadora e interlocutora Bruna Francheto. O fato de ter trabalhado com ela em seus projetos de linguística parece ter sido o que o levou a escrever sobre a socialidade "misturada" xinguana a partir da língua, transpondo para sua escrita a pluralidade entre vozes, idiomas e estratégias linguística e antropológica.
} 
à narrativa. Estamos no meio de um percurso, já bastante afastado daquele tempo em que indígenas eram meros objetos de pesquisa, reduzidos a nativos filmados por antropólogos que explicavam o que os nativos estavam fazendo. Aliás, o que se vê em filmes realizados por projetos compartilhados de cinema indígena são processos em que a realização do filme passa pelo controle dos mais velhos nas aldeias ${ }^{13}$. O que nos interessa, aqui, é uma reflexão a respeito de como, a partir dos "pactos etnográficos" estabelecidos para a realização e distribuição de filmes, e também das demais alianças - entre gerações, entre famílias e aldeias, ou xamânicas -, esse "cinema indígena mesmo" tem sido um suporte e um exercício dos modos locais de saber e conhecer ${ }^{14}$.

\section{Versões de Filmes}

Um dos aspectos que mais tem chamado minha atenção diante da produção de filmes entre coletivos e realizadores indígenas das terras baixas, já mencionado antes, é o fato de que, um modo necessariamente coletivo, a atividade com o vídeo reforça o hábito de se filmarem muitos eventos semelhantes, criando-se filmes e versões de si mesmos, de um modo análogo às inversões e repetições que encontramos na composição de narrativas míticas ameríndias.

Quando os Maxakali me mostram um novo filme realizado durante um ciclo ritual ou uma caçada específica que já havia sido filmada outras vezes, ou quando propõem filmar um novo filme inclusive com o mesmo título de um filme anterior, entendo que aquele tipo de cinema compõe um sistema que continuamente se abre para uma nova variante. Cada caçada - um evento sempre ritual - é uma versão de outra, e por isso "mereceria" seu próprio filme. Para citar outros exemplos, o filme "Tatakox" (2007), de

\footnotetext{
${ }^{13}$ Muitos filmes, inclusive, mostram as pessoas (mestre, pajés, conselhos de anciãos) negociando ou declarando seus interesses a respeito do que será mostrado.

${ }^{14}$ A respeito de experiências com a formação de cineastas indígenas e suas produções, Callois e Carelli pontuaram que: "construir, através da mídia audiovisual, informações para o público leigo ou para o círculo restrito dos especialistas representa certamente uma experiência valiosa para a reflexão antropológica. Mais interessante ainda é construí-las com e para os sujeitos da pesquisa: as comunidades indígenas. Retorno, feedback, antropologia interativa ou compartilhada, como pregava Jean Rouch, são princípios muitas vezes declarados, mas raras vezes concretizados. [...] O projeto de vídeo do CTI se propõe inverter e enriquecer essa relação. Ao invés de simplesmente se apropriar da imagem desses povos para fins de pesquisa ou difusão em larga escala, esse projeto tem por objetivo promover a apropriação e manipulação de sua imagem pelos próprios índios. Essa experiência, essencial para as comunidades que a vivenciam, representa também um campo de pesquisa revelador dos processos de construção de identidades, de transformação e transmissão de conhecimentos, de formas novas de auto-representação" (Gallois; Carelli, 1995: 67).
} 
Isael Maxakali, motivou a realização do "Tatakox Vila Nova" (2009), de Guigui Maxakali, que tinha a intenção de incluir o que estava faltando no primeiro. Desde então, já assisti a dezenas de filmes de Tatakox, cada uma delas a versão definitiva, a mais correta. Do mesmo modo, no filme "A festa da moça" (1987), produzido entre os Nambiquara, um ritual de iniciação feminino filmado motivou a realização e filmagem de outro que há décadas não se realizava, a furação dos lábios masculinos. Divino Tserewahú, após fazer "Wai'á Rini" (2001), foi convocado a fazer outro filme sobre o mesmo ritual na aldeia vizinha. Em "O Amendoin da Cotia" (2005), os Panará haviam visto uma corrida de tora num filme sobre os Krahô, e quiseram filmar sua corrida para demonstrar que aquilo também fazia parte das suas tradições. Parece que esse modo de o vídeo muitas vezes incitar a realização de um ritual, mas mais que isso, de outras versões, análogas, ou em outra localidade, aproxima-se de um costume de um ritual sempre motivar a realização de outro, ou em outra aldeia. Um filme-ritual provoca a realização de uma variação filmada desse ritual. Ou de um ritual inverso. Ou em outro local (em outras aldeias, entre outras etnias).

A partir de toda a minha experiência de campo e de sessões de transcrição de cantos que pude acompanhar ao vivo e a partir de vídeos, a respeito do cuidado com o registro dos yãmĩyxop (os rituais com a presença dos aliados xamânicos dos Maxakali), e de uma certa preocupação com a legitimidade para tratar corretamente de assuntos xamânicos - ou seja, que envolvem uma certa política diplomática, uma experimentação de encontros e jogos perspectivos -, percebo que os modos como os Maxakali celebram seus encontros com os yãmĩy não se dão por acaso. Na relação figura-fundo entre invenção e convenção, aquilo que parece ocorrer de forma desordenada, insuficientemente ensaiada para um registro definitivo, na verdade é um conjunto de variáveis minuciosamente propostas para aquele evento, seja pela tradição, seja pelas escolhas dos próprios yãmĩy, ou determinação dos pajés. Vemos nas gravações e nas experiências no campo que cada aspecto sonoro, mítico, visual, ritual, narrativo, pode ser realizado de várias maneiras diferentes, ou em várias versões de si mesmas, conforme a vontade dos que os conduzem diante dos contextos em que se realizam tais eventos. A variação é parte constitutiva desse corpus, e produzir uma espécie de registro material de cantos, histórias e rituais coloca-nos diante dessa condição. Ora uns reprovam o que foi produzido por outros alegando conter erros, ora repete-se diferindo como se o que diferisse entre produções rituais, gravações, narrativas e explicações diversas, consistisse 
mais num modo próprio de construção e transmissão daquilo que se pretende registrar ou comunicar, do que propriamente numa contradição.

Sabemos que, diante de qualquer impasse a respeito desse corpus, devem-se consultar os pajés - especialmente os mais velhos, que conhecem mais os yãmĩy. Não podemos supor que qualquer elemento variável - sonoro, visual, narrativo - que percebemos nos yãmĩyxop ou nos mitos, não se conecte a uma estrutura. Nenhum detalhe, por mais insignificante que possa parecer, é gratuito. As variantes que despontam em cada evento - ou cada repetição - não podem ser tomadas como se floreassem, de modo aleatório ou incerto, aquilo que se pretende registrar ou transmitir de fato. Elas se produzem com rigor, afinal, como nos ensina Lévi-Strauss, a complexidade das armações possíveis mostra justamente que não se conecta qualquer coisa com qualquer coisa. O que se realiza durante uma narrativa mítica, uma produção ritual e uma filmagem é um rigoroso exercício, que envolve negociações às vezes inesperadas e incansáveis entre pajés. O que seria esse exercício que é realizado tanto na narrativa mítica como na realização ritual, com relação ao pensamento mítico? Serão os mitos pensando a si mesmos e se transformando através dos narradores?

\section{Pactos etnográficos e "Cinema-Verdade"}

Recentemente, tivemos acesso à tradução de um dos poucos livros que se constitui como um espaço de criação compartilhada. Trata-se do A Queda do Céu (Kopenawa e Albert, 2011), um "acontecimento cientifico incontestável" (Viveiros de Castro, 2011: 01), onde um antropólogo e um xamã yanomami conseguem, a partir de trinta anos de trabalho, formular um discurso compartilhado na forma e no conteúdo, mas também um "acontecimento politico e espiritual muito mais amplo" (Ibidem), por trazer uma antropologia também reversa, na qual nos confrontamos com a triste imagem da relação entre a civilização cristã-ocidental com o resto do mundo.

Davi Kopenawa, assim como grande parte dos interlocutores que aparecem na literatura a respeito da produção autobiográfica ameríndia ( $c f$. Oakdale, 2007; Calavia, 2007; Mehinaku, 2010, dentre outros), aliou durante muitos anos sua experiência diplomática xamânica e seu esforço como agente de contato interétnico com a civilização "Branca", e enuncia-se como representante de um povo que nasceu "no centro da ecologia". Ele denuncia a potência destrutiva e o pensamento "cheio de esquecimento" 
do ocidente, ao mesmo tempo em que compartilha seu olhar e sua formação xamânica: um modo relacional de produção e partilha de saberes, que recusa a experiência objetificante do mundo e se permite "ser olhado" por uma grade pluralidade de gentes e pontos de vista.

A Queda Do Céu é um dos resultados de um excepcional, crítico, reflexivo, e certamente exaustivo processo de tradução discursiva, atenta às diferenças formais e contextuais entre os modos de conhecimento dos dois autores. $\mathrm{O}$ "pacto etnográfico" entre Albert e Kopenawa produz uma escrita pós-colonial, "tanto do ponto de vista políticodiplomático de sua possibilidade e pertinência, como daquele retórico-epistêmico" (Viveiros de Castro, 2011: 29) ${ }^{15}$.

\begin{abstract}
Albert está perfeitamente a par das controvérsias acesas pela crise pós-modernista em torno da (auto)biografia como gênero, da tensão entre o Eu do narrador e o do escritor, da "economia da pessoa" implicada na etnografia e do processo de "delegação ontológica" que veio renová-la (Salmon 2013), da alteridade 'própria' a toda autoria, e sobretudo da assimetria inerente à "situação etnográfica" e suas consequências epistêmicas (Zempléni 1984; Viveiros de Castro 2002), assimetria irredutível que o escriba/escritor de A queda do céu procura compensar, sem jamais pretender escondê-la, por um conjunto de soluções narrativas postas sob o signo do "menor dos males" (infra p. 536). Esta última expressão me parece particularmente feliz para caraterizar a essência do gênero etnográfico - "conhecimento aproximado" por natureza, diria Bachelard (ou antes, 'por cultura') —, e, mais geralmente, para designar a sensação de perda inevitável suscitada por todo trabalho de tradução, seja esta interlinguística, intercultural, intersemiótica, ou mesmo, como constatamos dolorosamente em nossa própria vida, interpessoal - para não falarmos naquela obscura, incessante e equívoca tradução intrapessoal que se estabelece no tumulto de nossas múltiplas vozes 'internas', sob a pressão implacável do inconsciente. E pouco importa, no final das contas, que a perda seja de fato puramente imaginária. Mais um equívoco (inevitável?) sobre o equívoco. (Viveiros de Castro, 2011: 30)
\end{abstract}

Cerca de cinquenta anos antes da publicação de A Queda do Céu, essa obra escrita que assume o equívoco e parte da diferença e do comprometimento com uma antropologia compartilhada para criar um discurso quase poético, um outro etnólogo buscava, através da criação dialógica, da estética surrealista e dos riscos assumidos pelo cinema-direto, experimentar uma relação antropológica também compartilhada e reversa. Trata-se de

\footnotetext{
15 Além do esforço de tradução, os autores também marcam a dualidade de vozes na construção do texto, seja descrevendo o encontro e o "pacto etnográfico" entre eles, seja apresentando notas, introduções, conclusões e epígrafes com autorias separadas.
} 
Jean Rouch, que realizou, cada vez mais em parceria com seus interlocutores do oeste africano, mais de uma centena de etnografias fílmicas ${ }^{16}$.

Inspirado por Dziga Vertov, Rouch utilizava o recurso do cinema-direto de um modo próprio, preferindo considerá-lo um "cinema-verdade", recusando tratar o que estava sendo filmado como simples objeto, mas propondo que a presença da câmera e relação fílmica se explicitassem, e que o próprio etnólogo-cineasta se deixasse afetar, numa experiência que chamou de "cine-transe" (Rouch, 2003 [1973]: 63). O compromisso com o contexto, as condições do ambiente, a fluência cotidiana da fala, dos gestos e do comportamento das pessoas filmadas; com a inventividade de filmadores e filmados ao descrever o mundo inclusive na dimensão do sonho; e com a relação estabelecida através do olhar e da escuta entre os corpos que filmam e os que são filmados, propunha uma linguagem cinematográfica na qual o roteiro prévio deixava de ser determinante, o que influenciou inclusive os cineastas da nouvelle vague. Além desse modo de filmar que colocava a relação na frente do roteiro, que foi se aprimorando ao longo de sua vida, todo o contexto de produção desses filmes foi sendo cada vez mais dialógico. Influenciado por Robert Flaherty e seu filme Nanook of the North (1922), Rouch compartilhava as imagens filmadas com seus interlocutores e acatava suas interpretações numa medida cada vez maior ${ }^{17}$.

A princípio, com um filme sobre a caçada a hipopótamos realizada pelos Songay do Níger, Bataille sur le grand fleuve (1951), ele assumiu o papel de um etnólogo cineasta e narrador, e os nativos filmados opinaram a respeito do filme pronto. Inspirado pela possibilidade de ampliar esse diálogo, o autor aos poucos foi desenvolvendo sua proposta de antropologia compartilhada, e a relação etnólogo/nativos e filmadores/filmados se transformou radicalmente, com equipes formadas em conjunto com seus interlocutores, e filmes e temas propostos por eles. Não tardou para que Rouch encontrasse como parceiros mais próximos os nigerenses Oumarou Ganda e Damouré Zika - que acabaram tornando-

\footnotetext{
${ }^{16}$ Rouch também publicou por volta de uma centena de textos escritos - quase nenhum traduzido para o português - que evidenciavam sua produção fílmica como lugar de seu pacto etnográfico compartilhado.

${ }^{17}$ Evidentemente, na relação entre o cineasta europeu e seus interlocutores africanos, havia elementos que dizem respeito às enormes diferenças não só de pensamento, mas de poder. Foi Rouch, que controlava o uso dos recursos materiais que possibilitavam a realização de filmes, quem optou por abrir mão de uma postura autoritária para propor esse compartilhamento, por entender que esse modo seria muito mais proveitoso. Ele compreendeu que, se era ele o mestre que detinha conhecimentos e instrumentos para a produção cinematográfica, as pessoas que lhe interessavam detinham conhecimentos a respeito daquilo que poderia ser filmado, e, portanto, quanto maior fosse a dimensão do compartilhamento da produção e dos respectivos saberes, mais potente seria a produção dos filmes-verdade.
} 
se cineastas, além de Lam Ibrahima Dia e Tallou Mouzourane. Juntos, realizaram filmes como Jaguar (1954-67), Moi, un Noir (1957-58), Petit à Petit (1968-70), Cocorico! Monsieur Poulet (1974), e Le Rêve Plus Fort Que La Mort (2002), submetendo a experiência cinematográfica e etnográfica a um processo inventivo compartilhado, muitas vezes caracterizado como "etnoficção". A obra de Jean Rouch não é apenas um conjunto de olhares sobre diversos grupos africanos, mas também é composta de olhares africanos sobre si mesmos, uns sobre os outros e sobre a sociedade de tradição cristã-ocidental.

Para citar um exemplo, Moi, un Noir (1957-58) foi narrado por Oumarou Ganda, cujos comentários e uma espécie de dublagem espontânea a respeito de sua personagem ${ }^{18}$ e dos lugares e situações filmados foram inseridos após as filmagens. Rouch também inseriu seus próprios comentários, que se entrelaçam dialogicamente com os de Ganda. Ambas as vozes adicionam camadas inventivas e interpretativas - e, segundo Rouch muitas vezes declarou (Rouch, 2003a: 140, Morin, 2003: 253), revolucionariamente poéticas - às imagens, expressando a análise e a própria vivência dos dois realizadores no contexto do filme, não apenas descrevendo a realidade - uma cultura, um povo objetivamente, mas atualizando-a e assumindo seu caráter fragmentário.

Rouch propunha um "pacto etnográfico" com seus interlocutores - cujos "termos" foram modificando-se e aprimorando-se ao longo de sua carreira - que produzia descrições etnográficas a partir da inventividade e do dialogismo entre as múltiplas vozes, compartilhando a realização e a autoria dos filmes. ${ }^{19}$ Afinal, Rouch sempre viu uma paridade epistemológica entre os antropólogos ou cineastas franceses e seus

\footnotetext{
${ }^{18}$ Jaguar, assim como os seguintes Moi Un Noir, Petit a Petit e Cocorico, "exprime o lugar conceitual dos acontecimentos, dos eventos e das relações engendradas entre seus personagens (incluindo aí Rouch) na construção de uma etnografia filmica. Seus personagens não são simplesmente biográficos ou culturais, são etnobiográficos no sentido que produzem uma problematização entre o individual e o coletivo, o sujeito e a cultura" (Gonçalves, 2008: 24). A peculiaridade do cinema rouchiano é a admissão de uma formulação inventiva, com elementos ficcionais e improvisados, desses personagens etnobiográficos. Inspirado pelo surrealismo, Rouch acreditava na potência da imaginação e do sonho como formação de um ponto-de-vista. A realização fílmica, tal como a descrição etnográfica, poderiam, então, produzir e dar a ver um "real imaginado", um entendimento subjetivo e experiencial do mundo, afastando-se da delimitação de um indivíduo como simples representação coletiva (Gonçalves, 2008: 109).

${ }^{19}$ Conforme Renato Sztutman (2009: 115): "Rouch procura escapar dessa acusação [de retratar os africanos cientificamente como insetos], ao menos no que se refere ao seu próprio trabalho, alegando que o próprio da antropologia é oferecer um olhar estrangeiro, e que uma verdadeira postura de simetrização de saberes e práticas não seria dada apenas com a oportunidade de os nativos - no caso, os africanos - filmarem eles mesmos os seus problemas, mas também com a oportunidade de eles filmarem os seus outros - por exemplo, nós mesmos. Rouch afirma: "A antropologia que se presta a estudar a cultura francesa deveria ser praticada por gente de fora da França. Para estudar a Auvergne ou a Lozère, é melhor que o etnógrafo seja um bretão". E ainda: "Meu sonho é que os africanos façam filmes sobre a cultura francesa!" (1982: 17)."
} 
interlocutores africanos, cujos saberes e modos de conhecer - suas propostas de trabalho e interpretações - levava bastante a sério (Sztutman, 2009: 113):

Ele tratou o pensamento e as práticas desses povos não como ilusões ou enganos, tampouco como fenômenos que só se explicam por um conceito exterior a eles como o de sociedade ou de inconsciente -, mas sobretudo com base nos próprios termos por eles empregados. Em outras palavras, ele sempre esteve aberto - mesmo quando fez filmes etnográficos mais clássicos - para ouvir as explicações e interpretações que os próprios nativos tinham a dar sobre a sua experiência, incorporando-as no produto final do filme. (Sztutman, 2009: 114)

Para Rouch, tanto o cinema quanto a etnografia partem, essencialmente, da relação entre sujeitos diferentes: "O cinema, arte do duplo, já é a transição do mundo real para o imaginário, e a etnografia, ciência dos sistemas de pensamento dos outros, é um permanente cruzamento entre um universo conceitual e outro" (Rouch, 2003b: 185). Entusiasmado com a inventividade compartilhada através da realização fílmica, sempre ressaltava as habilidades cinematográficas e etnográficas de seus companheiros nigerenses, e previa um futuro no qual a câmera participante - cada vez mais portátil passasse para as mãos daqueles que até então haviam estado apenas diante dela: "o antropólogo não terá mais o monopólio da observação (...). E é assim que o filme etnográfico nos ajudará a 'partilhar'a antropologia" (Rouch, 1979 [1973]: 71). ${ }^{20}$

\section{Cinema, antropologia, xamanismo}

Se, conforme espero ter exposto acima, o trabalho com o cinema permite um diálogo maior numa relação antropológica, e também uma maior autonomia dos realizadores com relação a formas e métodos colonizadores, é porque não trabalha a partir de conceitos, como o texto escrito ou o pensamento científico, mas antes com a experiência sensível, essa matéria própria do pensamento indígena conforme propunha Lévi-Strauss. Isso não significa que a escrita não permita esse exercício dialógico, ou uma composição entre pensamento mítico e ciência (e as Mitológicas não deixam de ser um

\footnotetext{
${ }^{20}$ Em 1977, Rouch foi convidado pelo governo de Moçambique e pela Embaixada da França a organizar, com Jacques d'Arthuys, uma oficina de cinema para alunos do Instituto Nacional de Cinema de Moçambique. Surgiu, como exercício, o curta-metragem Makwayela (1977). A partir dessa experiência foram criados os Ateliers Varan, em 1981, com o objetivo de formar cineastas em países onde ainda não houvesse uma produção cinematográfica e entre grupos étnicos e sociais que não tivessem acesso a técnicas e meios de produção do cinema. E eis que as oficinas Varan, ainda hoje, inspiram oficinas de realização audiovisual em aldeias indígenas no Brasil, cuja produção final circula entre diferentes etnias e constitui uma grande referência para a realização de novos trabalhos.
} 
exemplo disso). Cada vez mais, jovens indígenas no Brasil têm ingressado no ensino superior e em programas de pós-graduação, e experimentado formas de falar sobre si e sobre os outros de um modo não capturável pelas bases epistemológicas da academia. $\mathrm{O}$ percurso dessa produção - e da produção literária, de um modo geral - vai ser diferente do que tem ocorrido no cinema, com formulação de abstrações, passagens do contínuo ao discreto, para que um novo tipo de conhecimento seja produzido e compartilhado. Já vemos casos como o de narradores do Rio Negro, onde a produção de livros parece se articular com suas práticas sociais, rituais e xamânicas (Andrello, 2010).

O antropólogo Tukano João Paulo Lima Barreto, em sua dissertação sobre os saberes do benzimento (2013), propõe um exame a respeito da reflexão antropológica formulada de um ponto de vista indígena. O autor pontua que uma "antropologia indígena" não se dá pelo simples fato de o antropólogo ser indígena, mas sim pela disposição em pensar os conhecimentos a partir de uma perspectiva indígena, trabalhando seus conceitos e sua linguagem para formular uma "tradução antropológica".

\begin{abstract}
Não parece difícil (e já demos muita prova disso) exprimir os conhecimentos indígenas na forma de narrativa mitológica. No entanto, exercitar a reflexividade desse conteúdo de modo inteligível, numa certa lógica, pensando num diálogo com a Antropologia, constitui um esforço que nós, indígenas, não estamos acostumados a fazer. Menos ainda, não somos estimulados - diferentemente do que se faz com a produção mitológica - a pensar sobre nossos conhecimentos, a tratá-los na forma de conceitos ou teorias. O envolvimento de indígenas nos projetos e estudos, toma por base quase sempre a matriz e a metodologia científica, onde os indígenas aparecem reproduzindo as teorias "de fora para dentro". (2013: 25)
\end{abstract}

A princípio, Barreto propunha-se estudar como a ciência dita ocidental formula objetivamente seus conhecimentos a respeito dos peixes, para então contrapor ao entendimento Tukano a respeito dos "humanos invisíveis" e sua relação com a categoria dos peixes. No entanto, ao se ver diante de seu pai, um especialista em benzimentos, como interlocutor, e seguindo as provocações de seu orientador, viu-se obrigado a sistematizar melhor seu conhecimento tukano, trazendo seus saberes para uma posição mais simétrica em relação ao conhecimento científico. Nesse esforço, confrontado pelo pai, Barreto se deu conta de que havia uma grande diferença entre uma formação como benzedor e detentor dos saberes do benzimento e uma aprendizagem dos conhecimentos a respeito do benzimento que o capacitasse a escrever e falar sobre isso. Trata-se de uma diferença entre um saber fazer e um conhecer objetivamente. Sua opção metodológica foi por 
sistematizar, em termos antropológicos, os conhecimentos tukano (2013: 28), sem, no entanto, substituir os paradigmas ${ }^{21}$ tukano pelos científicos.

No caso do uso do cinema como método etnográfico, como vimos, essa diferença metodológica se dissolve em outro tipo de relação. É claro que o u so das imagens filmadas pode objetificar um conhecimento, mas o que ocorre no cinema que tem sido produzido por indígenas no Brasil (esse "cinema indígena mesmo", para "registrar no cartório") é uma descrição necessariamente relacional e polifônica, na qual os modos de socialidade e a forma sensível nativas são utilizadas, sob o controle dos especialistas. Por isso vemos frequentemente cineastas indígenas comprometidos com a atividade política e xamânica nas suas aldeias. Muitas vezes, entre os Maxakali, tivemos que interromper uma atividade de legendagem ou edição porque os cineastas estavam sendo convocados pelos pajés a cantar e compartilhar narrativas na kuxex, ou casa dos cantos. Quase todos os cineastas indígenas acabam se tornando também lideranças, professores, caciques, ou ainda se candidatam a cargos políticos em sua região.

Bruce Albert descreve contextos em que novos tipos de "lideranças" indígenas tem surgido, operando uma nova "aliança de competências cosmológicas e interétnicas" (Albert, 2002: 245). Afinal, o procedimento a ser operado em situações de tradução intercultural também pode ter um aspecto xamanístico. Trata-se de um exercício criativo de interpretação e reconstrução de variados olhares e discursos, no qual o cineasta, assim como o xamã, mobiliza inventivamente princípios cosmológicos e conceitos nativos (Ibid.: 250), para estabelecer traduções e relações com seus interlocutores estrangeiros experimenta aquela condição que permite "reunir em si mais de um ponto de vista" (Carneiro da Cunha, 2009: 113).

Entre os Maxakali, muitos se apresentam como cineastas e como lideranças, tanto nas aldeias, quanto nas muitas oportunidades que tem tido de participar de atividades fora delas, acompanhando exibições em festivais e exposições, conhecendo outros cineastas, ou trabalhando em conjunto com os não-indígenas, nas cidades. É bastante aparente o quanto tais experiências permitem aos cineastas se colocarem numa posição diferenciada

\footnotetext{
${ }^{21}$ Chamando atenção para a adoção metodológica de um paradigma indígena, Márcia Nunes Maciel (2016) também realiza operações em sua própria linguagem e conceitos para reconstruir através da escrita "Costurar com as Mãos" - o fio da memória das tradições Wajuru: sem "trocar os sapatos", ou seja, partindo de paradigmas Wajuru em vez de abandoná-los pela sistematização epistêmica proveniente da disciplina acadêmica com a qual trabalha.
} 
diante dos outros, conferindo-lhes um papel de tradutor e representante entre nãoindígenas e parentes de outras etnias ${ }^{22}$.

Se o cinema traz a possibilidade de reunir diversos pontos de vista operando traduções e narrativas e interpretações compósitas, de um modo tão próximo das cosmopolíticas dos caciques e dos xamãs, retomemos a proximidade desse esforço tradutivo com relação ao próprio fazer etnográfico, o que constitui o cinema como grande instrumento de antropologia compartilhada, tal como propunha Jean Rouch. Acompanhando o pensamento de Eduardo Viveiros de Castro (2004: 04), entendemos que fazer antropologia não é nada mais - nem nada menos - que comparar antropologias, culturas que são elas mesmas conjuntos de comparações. Entretanto, o autor pontua que essa comparabilidade, que é nossa matéria prima e nosso terreno por excelência, como sugere Marilyn Strathern (2013 [1987]), não significa imediatamente uma tradutividade: "Como recuperar as analogias traçadas por povos amazônicos nos termos de nossas próprias analogias?" (2004: 04). Viveiros de Castro propõe, então, a noção de "equivocação", na tentativa de reconceituar, com a ajuda de uma antropologia ameríndia perspectivista, o procedimento comparativo, que concerne ao processo envolvido na tradução da prática e dos conceitos discursivos nativos em termos do aparato conceitual da antropologia. Isso necessariamente inclui o discurso do antropólogo ou interlocutor não-indígena como um dos termos dessa comparação, e a coloca a serviço da tradução, não o oposto.

\footnotetext{
${ }^{22}$ Manuela Carneiro da Cunha (2009: 102-113), ao desenvolver uma reflexão sobre a tradução e o xamanismo, sugere o quanto esse tipo de experiência de viajar para fora para exercer funções e participar de projetos que vão tomando importância nas aldeias é determinante na formação de lideranças indígenas, e crucial para o desenvolvimento de suas habilidades de tradução interétnica. Terrence Turner (1992) também já havia percebido esse fenômeno entre os Kayapó: "As video takes on political and social importance in an indigenous community, which member of the community assumes the role of video cameraperson, and who makes the prestigious journey to the alien city where the editing facilities are located, become issues fraught with social and political significance, and con-sequently, social and political conflicts." (Turner, 1992: 6). Aliás, tal constatação é frequente no contexto de formação de cineastas e produção audiovisual nas aldeias: "Nos diversos contextos, uma percepção comum foi quanto ao poder que deriva da apropriação dos meios de comunicação audiovisual. Nas oficinas evidencia-se o valor simbólico que deriva da posse da câmera; tê-la em mãos resulta numa inserção diferenciada do seu detentor dentro do grupo. Além disso, com o vídeo reforça-se a possibilidade de narrar a experiência, para o próprio grupo e para os seus outros. Em situações nas quais os sujeitos são marcados pela invisibilidade, a produção de imagens pode ter um valor estratégico para a emergência de um gradiente de novas vozes. [...] No caso bororo, também há uma grande valorização da posse da câmera como um elemento de status. Os jovens bororo que utilizavam a câmera podiam potencializar seu desejo de maior influência política, algo que raramente é acessível a eles. Ser um "câmera" permitia a participação nas discussões políticas e reivindicatórias e viajar para registrar rituais e negociações. No entanto, essas possibilidades tinham suas limitações também. Esses jovens que tinham acesso a elementos do mundo dos "brancos" podiam atuar e exercer algum poder oriundo dessa situação dentro dos limites estritos que sua inserção social e cerimonial permitia." (Ferraz, A. L. M. C. [et al.], 2006: 292)
} 
A equivocação não é o que impede a relação, mas o que a funda e impele: a diferença de perspectiva. Para traduzir é preciso presumir que um equívoco sempre existe, e é isso que comunica as diferenças ao invés de silenciar o outro presumindo uma univocidade - a similaridade essencial - entre o que o outro e nós estamos dizendo. (Viveiros de Castro, 2004: 08). Pedro Cesarino, que dedica-se bastante à interpretação e tradução de desenhos e cantos xamânicos dos Marubo, assume tal tarefa como uma "recriação poética" (2012: 80):

\begin{abstract}
Mesmo que bastante próximo do original em marubo, [o texto em português] pretende reinventar na escrita a elaboração verbal presente no canto; busca estabelecer no português algo do registro paratático original, que tenderia a desaparecer na escrita em prosa linear. Daí o uso parcimonioso da pontuação, das preposições e dos artigos para destacar os núcleos imagéticos, os paralelismos e o fluxo rítmico. Tanto melhor se, no final, o texto causar estranhamento, pois é esse o registro dessa poética tornada acessível pela reinvenção criativa. Desde que ele seja capaz de levar o leitor a percorrer o sentido de tal estranheza, alguma tarefa estará cumprida. (2012: 80)
\end{abstract}

Cesarino aproxima, ainda, sua tarefa etnográfica de um fazer xamânico, e considera que "o caráter propriamente tradutório do xamanismo marubo reside, pois, nessa capacidade de transporte entre conhecimentos e referências inacessíveis à experiência ordinária dos viventes" (2012: 81-82). A ideia de que os xamãs, "viajantes no tempo e no espaço", sejam tradutores, segundo a antropóloga Manuela Carneiro da Cunha (1998), não é trivial:

Cabe-lhes, sem dúvida, interpretar o inusitado, conferir ao inédito um lugar inteligível, uma inserção na ordem das coisas. [...] Como se escrutasse por apalpadelas, como se abordasse um domínio desconhecido cujos objetos só se deixam ver parcialmente, o xamã adota uma linguagem que expressa um ponto de vista parcial. (1998: 12-13)

Trata-se, segundo a autora, de um jogo "no qual a linguagem, em seu registro próprio, manifesta a incerteza da percepção alucinada", de mundos onde só se veem sob perspectivas particulares. Uma boa tradução seria, assim, não a que busca "restituir fielmente os objetos designados, já que, afinal de contas, nas diferentes línguas todos os objetos fazem parte de conjuntos, de sistemas diferentes", mas sim aquela que "é capaz de apreender os pontos de ressonância, de fazer com que a intentio em uma língua reverbere em outra." (1998: 13) A tarefa do tradutor, para Carneiro da Cunha, aproximase da sensibilidade dos xamãs às dificuldades das "passagens entre códigos que jamais 
são inteiramente equivalentes", em sua tentativa de reconstrução do sentido ao estabelecerem relações (p. 14).

Talvez seja este o sentido de uma aproximação entre o fazer etnográfico, o exercício de tradução constitutivo do xamanismo, e o cinema "indígena mesmo". O que surge dessas experiências é, precisamente, o resultado dos diálogos intersubjetivos, das traduções, interpretações e criações experimentadas em campo (e extracampo), e de um modo talvez mais potente do que em produções escritas, porque baseado na experiência sensível, nos corpos e nos olhares, na experimentação e na partilha de pontos de vista.

Diante do exposto, seria possível caracterizar o cinema como um suporte e um exercício de regimes de conhecimento indígena capaz de superar a objetificação científica colonizante de um olhar externo e autoritário? Como a relação fílmica e seu contexto articulam sistemas e práticas de conhecimento através da interlocução, de pactos etnográficos e produção compartilhada, permitindo uma atualização de tradições, um estabelecimento de relações entre corpos, pontos de vista e concepções de pessoa e de realidade, intensificado pelo exercício inventivo e político do olhar e da escuta?

Vimos em algumas etnografias o modo como saberes são compartilhados de modo inventivo (Nunes, 2016), fragmentário (Graham, 1995), polifônico (Deleage, 2007), relacional. Isso também é permitido pelo cinema inspirado no estilo de Jean Rouch. No contexto africano da migração e da experiência do transe e da possessão, as concepções nativas provocavam aquilo que o autor considerava um "cine-transe" (1979[1973]). No contexto ameríndio, o que se produz talvez seja um "cine-xamanismo", uma ressonância entre a relação fílmica e as relações cosmopolíticas implicadas nos processos filmados e de filmagem. A relação controlada de afecção e negociação entre quem filma e quem é filmado permite um exercício de presença, partilha, encontro, em vez de uma representação objetificante e colonizadora. O "cinema indígena, mesmo", produção não individual, mas sempre compartilhada (entre pajés, mestres e anciãos, mulheres, cineastas, parceiros e interlocutores não-indígenas), de modo que a própria mise-en-scène deixe ver o modo de fazer/verouvir a imagem e o som, o ritual ou a coisa filmada, parte da experiência sensível para reestabelecer um contínuo no mundo. Sendo produzido a partir da relação entre os corpos que se afetam através do olhar e da escuta (incluindo o não-visto, o fora-de-campo, o extracampo; dissolvendo a posição de um indivíduo que se pensa e pensa o mundo em torno de si), talvez seja aquele que permite 
o que Gersen Baniwa (2008) propõe para uma antropologia indígena intercultural e descolonizada:

\begin{abstract}
que a disciplina ceda lugar a indisciplina metodológica para dar lugar à diversidade, ao inesperado, ao sonho humano, ao possível e sobretudo à busca pelo desconhecido e pela liberdade de pensar, de fazer e de viver; e estimular e valorizar o espontâneo, o que não é conduzido, pelos dogmas criados e impostos, para que o homem recupere sua capacidade de pensar, inventar, criar, acertar e errar, enfim ser humano e não máquina ou peça de uma máquina pré-moldada, ou seja humano como humano ou o índio como índio. (2008: 10)
\end{abstract}

\title{
Boas distâncias
}

Para concluir provisoriamente, convém lembrar que um dos temas mais trabalhados em "A Origem dos Modos à Mesa" (2006 [1968]: 460) parece ser a lógica ou a ética da "boa distância". Os percursos dos astros, os ruídos produzidos ao comer, a conquista da sogra ciumenta, o controle do atravessador trapaceiro, a escolha de um cônjuge nem incestuoso nem radicalmente distante, tudo remete ao cuidado para que as coisas funcionem bem no mundo. As escolhas e ações desmedidas de um herói ou uma heroína afetam todo o curso da vida, e por isso são reguladas pelos mitos. Ao mesmo tempo, convém observar que quase sempre são os deslizes, os acidentes, as instruções não obedecidas é que produzem aberturas: o silêncio das rãs na primavera, o surgimento de um tipo novo de pássaro ou planta, o cuidado com um território e as espécies a serem caçadas a cada estação, o acordo com o sol para que o dia e a noite se intercalem, para que haja luz, para que o mundo não resseque nem seja destruído por um dilúvio. Mas tudo isso já aconteceu, o mundo encontrou suas periodicidades (do dia e da noite, do nascimento, da velhice e da morte, das estações), e agora é uma regulagem que a moral dos mitos realiza.

Boas distâncias em perpétuo desequilíbrio, e a consciência de que uma pequena ação pode produzir efeitos radicais. Cuidados para que as coisas não desandem, e não para que o mundo não ameace o "eu", que a essa altura realmente não existe. Eis que, em 1968, as Mitológicas nos alertavam para o humanismo dos mitos, que não começa no indivíduo, mas "coloca o mundo antes da vida, a vida antes do homem, o respeito pelos outros seres antes do amor-próprio" (2006 [1968]: 460). Como acrescenta Renato Sztutman a respeito desse pensamento "à esquerda" de Lévi-Strauss: 
Quando ele escreve aquilo, acho que em 1968, isso pode não ter surtido tanto efeito, mas hoje se a gente for pensar em termos de filosofia política, a questão da natureza, do mundo natural voltou no centro. Vide os trabalhos de [Bruno] Latour, do Políticas da Natureza, a própria ideia da Isabele Stengers de cosmopolítica, toda discussão hoje em torno da ecologia política, quer dizer, a ecologia, o mundo deixou de estar fora da política para estar dentro. E isso porque a gente sabe hoje, mais do que nunca, que se esse mundo ficar fora, o mundo vai, provavelmente acabar. Temos que trazer essas coisas para dentro da política, é o que o Latour está dizendo. O parlamento das coisas, que o próprio Viveiros de Castro tem discutido bastante. Isso estava no Lévi-Strauss, mas ele escreveu isso em 1968, 1969, num momento inclusive em que estava sendo pichado nas paredes das ruas que o estruturalismo não desce às ruas. Justamente uma das críticas que se faz ao estruturalismo é que não se extrai dele uma política. (2015, $\mathrm{s} / \mathrm{p})$

As Mitológicas podem ser lidas como uma produção mítica, ou em ressonância com o pensamento mítico, como uma variação dele, e que com o passar dos anos permanece sendo atual. Uma composição tão complexa de fechamentos e aberturas como essa permite constantes derivações e desdobramentos, como se "quase tudo" já estivesse lá, em perpétuo movimento. Deste ponto, a produção do cinema talvez também se aproxime: um registro é produzido para "mostrar" às gerações posteriores como se vivia "antigamente", e permite ver o que se transformou e o que morreu, contrapondo uma eternidade produzida pelo filme à atualização e aos desdobramentos daquele retrato anterior, que poderia ter sido feito em outro ponto de partida.

Aproveito para lembrar que, assim como a análise estrutural nas Mitológicas se realiza pelos olhares ora amplos, ora minimalistas, ora de perto, ora de longe, sendo possível produzir e demonstrar um pensamento composto de eixos transversais de diferentes dimensões, ritmos e em diferentes direções, também o cinema só se produz a partir desse procedimento, dessa experimentação de pontos de vista e de distâncias. Os pajés Maxakali, por exemplo, cantam para suas sobrinhas "aprendam a olhar ouvindo", e instruem a todos, filmadores ou não, a não se aproximar demais dos yãmĩy, a filmá-los de forma tangente. Um olhar demasiadamente direto e próximo poderia afetar de modo terrível a relação com esses aliados, e com isso afetar o mundo: também houve um dilúvio entre os Maxakali...

O exercício realizado até aqui permite considerar que o pensamento, identificado por Lévi-Strauss como a passagem da natureza à cultura ${ }^{23}$, seria um procedimento que

\footnotetext{
${ }^{23}$ Foi crucial compreender que tal passagem, seja ou não irreversível, não tem nada do que seria um sentido evolucionista ou etnocêntrico. Nem tampouco propõe que exista uma natureza única e culturas que se organizam subjetivamente com relação ao mundo, ou que isso seja tudo. A natureza é o nome que LéviStrauss dá para o contínuo no qual tudo e todos se estendem, num mesmo plano, e que é um estado perseguido pela atividade xamânica. A cultura, portanto, não é uma coisa fixa, mas um modo de produzir
} 
identifica elementos discretos, estabelecendo descontinuidades, pequenas ou enormes, a depender do ângulo que se analisa, no que seria um contínuo: natureza e cultura, dia e noite, humano e animal, inverno e primavera, inimigo e afim, vento e nevoeiro... Cada termo, no recorte seguinte, se converte no outro com relação um terceiro, e assim por diante, e é essa constante diferenciação através dos eixos de transformações que vão surgindo é o que constitui o pensamento. Esse parece ser o interesse fundamental das Mitológicas. O ritual, o xamanismo, seria o movimento inverso, que reestabelece um contínuo cromático em relação à ordem da natureza, através dos gestos fragmentários e das repetições. Através da repetição xamânica, que reintroduz diferenças infinitesimais na descrição do mundo, dos cantos, dos gestos e dos grafismos, é possível não mais utilizar diferenciações boas para pensar, categorizar, conceituar, mas utilizar microdiferenças boas para produzir experimentações de olhares outros, percursos, transformações corporais (o corpo não como dispositivo que objetifica todo o resto mas que afeta e se deixa afetar pelo cosmos). O cinema, tal qual o concebemos aqui, talvez esteja no meio do caminho, realizando procedimentos do pensamento, mas também procedimentos rituais, e seguindo essa direção. Um cinema que esteja na direção oposta, dedicando-se à fragmentação da vida para apenas pensar, não é cinema, mas atividade científica, ou, ao afastar-se do pensamento mítico, produção de espetáculo pelo mecanismo da representação. O cinema pensa o mundo e se pensa, mas produz experiência sensível, produz, suspende e se abre para relações e movimento, age pela continuidade do mundo.

\section{Bibliografia}

Albert, Bruce. 2002. O ouro canibal e a queda do céu. In: B. Albert \& A. R. Ramos (Organizadores) Pacificando o branco. Cosmologias do contato no Norte-Amazônico. São Paulo: Editora UNESP: Imprensa Oficial do Estado.

Andrello, G. 2010. Fala, objetos e corpos. Autores indígenas no alto rio Negro. In: Revista Brasileira de Ciências Sociais. vol. 25, n. 73.

Baniwa, G. 2008. Antropologia Indígena: O Caminho da descolonização e da autonomia indígena. Comunicação na ABA.

microdiferenciações e relacioná-las, é o próprio pensamento, é uma atividade que aponta para não ser o outro, mas para estabelecer graus de diferenciação entre o que deve estar próximo e o que deve estar distante para que o mundo funcione de maneira adequada. A oposição entre os dois termos sempre é relacional, e sempre se reconfigura de acordo com o eixo de transformações que é examinado. 
Barreto, João Paulo Lima. 2013. Wai-mahsã: peixes e humanos. Um ensaio de antropologia indígena. Dissertação de mestrado em Antropologia Social. Manaus: Universidade Federal do Estado do Amazonas.

Benjamin, W. 1994 [1936]. O narrador: considerações sobre a obra de Nikolai Leskov. São Paulo: Brasiliense, 1994: 197-221.

Brasil, André. 2012. O olho do mito: perspectivismo em Histórias de Mawary. Revista Eco Pós, Rio de Janeiro, v. 15, n. 3.

Caixeta de Queiroz, Ruben. 2008a. Do movimento ao fixo (e vice-versa) em Lévi-Strauss. In: Caixeta de Queiroz, Ruben; Nobre, Renarde (Orgs.). Lévi-Strauss: leituras brasileiras. Belo Horizonte: Editora UFMG.

2008b. Cineastas Indígenas e pensamento selvagem. In: Revista Devires Cinema e Humanidades, 5 (2), pp. 98-125.

Carneiro da Cunha, Manuela. 1998. Pontos de vista sobre a floresta amazônica: xamanismo e tradução. Revista Mana, 4(1), 7-22.

Cesarino, P.N. A escrita e os corpos desenhados: transformações do conhecimento xamanístico entre os Marubo. Revista de Antropologia, vol.55, 2012, pp. 75-137

Comolli, Jean-Lous. 2008 [1988]. Ver e Poder. a inocência perdida: cinema, televisão, ficção, documentário. Belo Horizonte: UFMG.

Deleage, Pierre (2007). "A Yaminahua Autobiographical Song: Caqui Caqui," Tipití: Journal of the Society for the Anthropology of Lowland South America: Vol. 5: Iss. 1, Article 5.

Deleuze, G. 1985. A Imagem-Movimento. São Paulo: Brasiliense. - (Cinema 1). . 2007. A Imagem-tempo. São Paulo: Brasiliense. - (Cinema 2).

Estrela da Costa, A. C. 2015a. Cosmopolíticas, olhar e escuta: experiências cinexamânicas entre os Maxakali. Belo Horizonte: Universidade Federal de Minas Gerais. Dissertação (Mestrado em Antropologia).

. 2015b. Pescando imagens: presença e visibilidade nos domínios do cinema de caça e pesca. In: Revista Devires - Cinema e Humanidades, Belo Horizonte, UFMG, v. 11, n. 2, jul./dez. p. 122-153.

Ferraz, A. L. M. C; Cunha, Edgar T.; Hikiji, Rose Satiko. 2006. O vídeo e o Encontro Etnográfico. In.: Cadernos de campo, 14/15. p: 287-298.

France, Claudine de. 1998 [1982]. Cinema e Antropologia . Campinas: Ed. Unicamp.

Gallois, Dominique; Carelli, Vincent. 1995. Vídeo e diálogo cultural: experiência do Projeto Vídeo nas Aldeias. Horizontes Antropológicos, ano 1, n. 2: 61-72, jul./set.

Gonçalves, Marco Antônio. 2008. O real imaginado: etnografia, cinema e surrealismo em Jean Rouch. Rio de Janeiro: Topbooks. 
Graham, Laura. 1995. Performing Dreams. Discourses of Immortality among the Xavante of Central Brazil. Austin: University of Texas Press. 290 pp.

Kopenawa, Davi; Albert, Bruce. 2010. La chute du ciel: paroles d'un Chaman Yanomami. Paris: Terre Humaine, Plon.

Lévi-Strauss, Claude. 1957 [1955]. Tristes Trópicos. São Paulo: Anhembi. 2007 [1962]. O pensamento selvagem. Campinas: Papirus. 2006 [1968]. A origem dos modos à mesa. São Paulo: Cosac Naify. 2011 [1971]. O Homem Nu. São Paulo: Cosac Naify. 1993 [1991]. História de Lince. São Paulo: Companhia das Letras.

Maciel, M. M. 2016. Tecendo Tradições Indígenas. Tese de Doutorado em História. São Paulo: Universidade de São Paulo.

Mehináku, Mutuá. 2010. Tetsualü: pluralismo de línguas e pessoas no alto Xingu. Dissertação de mestrado em Antropologia Social. Rio de Janeiro: Museu Nacional / Universidade Federal do Rio de Janeiro.

Morin, E. 2003. The chronicle of a film. In.: Cine-Ethnography. Jean Rouch, Steven Feld, ed. \& trans. Minneapolis: University of Minnesota Press.

Oakdale, Suzanne (2007) "Anchoring "The Symbolic Economy of Alterity" with Autobiography," Tipití: Journal of the Society for the Anthropology of Lowland South America: Vol. 5: Iss. 1, Article 4.

Rancière, Jacques. 2004. Malaise dans l'esthétique. Paris: Éditions Galilée. In.: Revista Devires - Cinema e Humanidades, 7 (2). 2008. Le Spectateur émancipé. Paris: La Fabrique. 2009. Le Destin des Images. Paris: La Fabrique.

Rouch, Jean. 1979 [1973]. La caméra et les hommes. In: France, Claudine. Pour une anthropologie visuelle. Paris, La Haye, New York: Mouton Éditeur.

2003a. "A life on the edge of film and anthropology. Jean Rouch with Lucien Taylor. In: Feld, S. Cine-Ethnography - Jean Rouch. (Visible Evidence, 13). Minneapolis, University of Minneapolis Press. pp. 129-148.

2003b. Jean Rouch with Enrico Fulchignoni: Ciné-Anthropology (Entrevista) In.: Cine-Ethnography. Jean Rouch, Steven Feld, ed. \& trans. Minneapolis: University of Minnesota Press.

Saez, Oscar Calavia. 2007. Autobiografia e liderança indígena no Brasil. Tellus. vol7/12

Strathern, M. 2013 [1987]. Fora de Contexto: As ficções persuasivas da antropologia. São Paulo: Terceiro Nome.

Sztutman, R. 2009. A utopia reversa de Jean Rouch - de Os mestres loucos a Petit à Petit. In.: Devires. N.6. Vol. 1 
2015. Sztutman, R; Matarezio Filho, E. T. . Sobre Lévi-Strauss e Filosofias

Indígenas - Entrevista Com Renato Sztutman. In.: Ponto.Urbe (USP), v. 16: 1-16

Tarde, Gabriel. 2007 [1895]. Monadologia e Sociologia. In.: Tarde, Gabriel. 2007. Monadologia e Sociologia: e outros Ensaios. São Paulo: Cosac Naify. 2007 [1910] Os Possíveis. In.: Tarde, Gabriel. 2007. Monadologia e Sociologia:

e outros Ensaios. São Paulo: Cosac Naify.

Taylor, A-C, \& Viveiros de Castro, E. 2006. "Un corps fait de regards." Qu'est-ce qu'un corps. Paris: Musée du Quai Branly/ Flammarion, pp. 148-99.

Viveiros de Castro, 2011. O Recado da Mata. In: Kopenawa, D. \& Albert, B. 2015. A queda do céu: palavras de um xamã yanomami. Tradução de B. Perrone-Moisés. São Paulo: Companhia das Letras.

2004. Perspectival anthropology and the method of controlled equivocation. In.: Tipití, v. 2, n.1:3-22.

Wagner, Roy. 2010[1975] A invenção da cultura. São Paulo: Cosac-Naify.

\section{Referências Fílmicas}

A Festa Da Moça

1987, 18'. Direção E Fotografia: Vincent Carelli. Roteiro: Gilberto Azanha E Virgínia Valadão. Edição: Valdir Afonso, Antônio Jordão E Cleiton Capellossi. Locução: Luiz Eduardo Nascimento. Tradução: Donaldo Mãmãinde.

Bataille Sur Le Grand Fleuve

1951, 33'. 16 mm, Kodacrome. Direção, Fotografia e comentários: Jean Rouch. Assistente: Roger Rosfelder. Com Damouré Zika, Illo Gaoudel, o chefe Oumarou e os pescadores Sorko de Firgoun, Ayorou e Koutougou. Canções: Kombine Katibaba, Sambalaga (Aïssata Gaoudelize), Ária dos caçadores (Yankori Beibatane), Ária dos remadores (Mallam Amisou), Canção de ninar (Hawa de Niamey).

Cocorico! Monsieur Poullet!

1974 / 92'. Direção: Jean Rouch, Damouré Zika, Lam Ibrahim Dia. Fotografia: Jean Rouch. Som: Moussa Hamidou e Hama Soumana. Montagem: Christine Lefort. Música: Tallou Mouzourane.

Darĩtidzé: Aprendiz de Curador

2003, 36'. Direção, imagens e edição: Divino Tserewahú. Imagens adicionais: Márcio Buru'ré. Oficina de edição: Leonardo Sette. Assistente de produção: Olívia Sabino. Coordenação: Mari Corrêa e Vincent Carelli.

Iniciação do Jovem Xavante 1999, 52' (Wapté Mnhõnõ ). Roteiro e direção: Divino Tserewahú. Imagens: Jorge Protodi, Winthi Suyá, Caimi Waiassé e Divino Tserewahú. Edição: Estevão Nunes Tutu, Marcelo Pedroso e Divino Tserewahú. Produção na aldeia: Bartolomeu Patira. 
Iniciação dos Filhos dos Espíritos da Terra

2015, 40'. Direção, fotografia e roteiro: Isael Maxakali. Montagem: Isael Maxakali, Suely Maxakali, Carolina Canguçu. Som: Isael Maxakali. Produção: Aldeia Verde Maxakali.

Jaguar

1954-67, 91'. Direção: Jean Rouch. Fotografia: Jean Rouch. Montagem: Josée Matarosso, Liliane Korb, Jean-Pierre Lacam. Som: Damouré Zika. Música: Enos Amelodon, Tallou Mouzourane, Amisata Gaoudelize

Kêtuwaje - Festa de Iniciação dos Jovens

2013, 104'. Direção: Mentuwajê Guardiões da Cultura. Fotografia e Som: Andre Cunihtyc Krahô, Debora Intohhôc Krahô, Edmar Cupakà Krahô, Ilda Patpro Krahô, João Batista Ropcuxy, Manduca Hãmpà Krahô, Marcio Jôc Krahô, Rodivan Raj Krahô, Silas Wôôcô Krahô, Tuira Pjêtyc Krahô. Montagem: Andre Cunihtyc Krahô. Produção: Centro Cultural Kàjre

Le Rêve Plus Fort Que La Mort

2002. Direção: Jean Rouch e Bernard Surugue.

Moi, un Noir

1957-58, 73'. Direção: Jean Rouch. Fotografia: Jean Rouch. Produção: Pierre Braunberger, Música: Joseph Yapi Degre. Montagem: Catherine Dourgnan e MarieJosèphe Yoyotte.

Nanook Of The North

1922, 79'. Direção: Robert J. Flaherty.

O Amendoin da Cutia

2005, 51'. Direção e Fotografia: Paturi Panará e Komoi Panará. Edição: Leonardo Sette, Vincent Carelli

Petit à Petit

1968-70, 96'. Direção: Jean Rouch. Assistente de direção: Philippe Luzuy. Roteiro: Jean Rouch, Damouré Zika, Lam Ibrahim Dia, Illo Gaoudel, Safi Faye, Tallou Mouzourane. Fotografia: Jean Rouch. Montagem: Josée Matarasso e Dominique Villain. Som: Moussa Amidou. Música: Enos Amelon, Alan Helly. Produção: Damouré Zika, Lam Ibrahim Dia.

Pi'õnhitsi, Mulheres Xavante Sem Nome

2009, 56'. Direção: Divino Tserewahú, Tiago Campos Torres Roteiro: Vincent Carelli, Amandine Goisbault, Divino Tserewahú , Tiago Campos Torres Edição: Tiago Campos Torres Locução: Divino Tserewahú

Tatakox

2007, 23'. Direção: Isael Maxakali. Câmera: Isael Maxakali. Montagem: Renata Otto, Douglas Campelo. Coordenação: Rosangela Pereira de Tugny.

Tatakox Vila Nova 
2009, 50'. Direção: Comunidade Maxakali Vila Nova do Pradinho. Fotografia: João Duro Maxakali. Montagem: João Duro Maxakali. Som: João Duro Maxakali. Produção: Comunidade Maxakali Vila Nova do Pradinho

Wai'á Rini: O Poder Do Sonho

2001, 48'. Direção, Fotografia E Roteiro: Divino Tserewahú. Edição: Valdir Afonso, Divino Tserewahú E Marcelo Pedroso. Coordenação: Vincent Carelli. Imagens Adicionais: Takoda Kazutaka. Assistente De Câmera: César Xavante. Imagens Wai'a 1987: Paulo César Soares. Produção Na Aldeia: Bartolomeu Patira. Depoimentos: Alexandre Tsereptsé, Bartolomeu Patira, Floriano Matsa, Genésio Oribiwe E Hipólito Tsahobo. [Com:] Celestino Tsererób'õ, Cesário Pari'õwa Dzéwa, Felix Nõmõtsé, Patrício 'Rãirõri, Pierina Wa'utó, José Meirelles, Lucas 'Ruri'õ, Márcio Buru'ré, Mariano Tsimhoné, Raimindo Tsererudu E Tiago Tsererudu. Tradução: Divino Tserewahú E Bartolomeu Patira. 